\title{
ANALISIS PENERAPAN PSAK NO.109 TENTANG ZAKAT, INFAQ DAN SHADAQAH PADA BADAN AMIL ZAKAT NASIONAL (BAZNAS) KABUPATEN NGANJUK
}

\author{
Juwita Ima Febriani Putri \\ Putri Awalina \\ Universitas Islam Kadiri Kediri \\ Email : Juwitaimafebrianiputri16@gmail.com
}

\begin{abstract}
Abstrak
PSAK No.109 tentang zakat, infaq dan shadaqah merupakan peraturan yang wajib diterapkan oleh lembaga pengelola zakat yang mendapat izin dari pemerintah seperti BAZNAS Kabupaten Nganjuk. PSAK ini bertujuan mengatur pengakuan, pengukuran, penyajian, dan pengungkapan transaksi zakat, infaq dan shadaqah. Dengan adanya PSAK ini diharapkan masyarakat luas dapat membaca laporan keuangan pengelola zakat dan dapat mengawasi pengelolaannya, sehingga terbangun kepercayaan masyarakat untuk menyerahkan zakat, infaq dan shadaqahnya kepada BAZNAS Kabupaten Nganjuk.

Penelitian ini merupakan penelitian kualitatif deskriptif. Teknik pengumpulan data menggunakan observasi dan wawancara untuk data primer dan data sekunder dari laporan atau catatan BAZNAS Kabupaten Nganjuk. Hasil penelitian ini menunjukkan bahwa BAZNAS Kabupaten Nganjuk belum menerapkan PSAK No.109 mulai dari saat pengakuan, pengukuran setelah pengakuan, hingga penyajian dan pengungkapannya. Hal tersebut dilihat dari hasil analisis perbandingan dengan yang tidak sesuai dan belum disajikannya 5 komponen laporan yang diatur dalam PSAK No.109. Selain itu, belum diungkapkan dana bagian amil dalam laporan keuangan dan juga kebijakan terkait penyaluran dana zakat, infaq dan shadaqah untuk amil dan mustahik nonamil.
\end{abstract}

Kata Kunci: PSAK No.109, zakat, infaq, shadaqah, BAZNAS.

\begin{abstract}
PSAK No.109 concerning zakat, infaq and shadaqah is a regulation that must be implemented by zakat management institutions that have obtained permits from the government such as BAZNAS, Nganjuk Regency. This PSAK aims to regulate the recognition, measurement, presentation, and disclosure of zakat, infaq and shadaqah transactions. With the existence of this PSAK, it is hoped that the wider community can read the financial reports of zakat managers and be able to
\end{abstract}


supervise their management, so that public trust is built to hand over their zakat, infaq and shadaqah to BAZNAS Nganjuk Regency.

This research is a descriptive qualitative research. Data collection techniques used observation and interviews for primary data and secondary data from reports or records of BAZNAS Nganjuk Regency. The results of this study indicate that BAZNAS Nganjuk Regency has not implemented PSAK No.109 starting from the time of recognition, measurement after recognition, to presentation and disclosure. This can be seen from the results of the comparative analysis which are not appropriate and the 5 report components stipulated in PSAK No. 109 have not been presented. In addition, the amil portion of the funds has not been disclosed in the financial statements as well as policies related to the distribution of zakat, infaq and shadaqah funds for amil and mustahik nonamil.

Keywords: PSAK No.109, zakat, infaq, shadaqah, BAZNAS.

\section{PENDAHULUAN}

Dalam rukun Islam yang ketiga setelah mengucap syahadat dan mendirikan sholat disebutkan untuk mengeluarkan zakat bagi yang mampu, sehingga membayar zakat merupakan kewajiban bagi setiap muslim yang mampu. Sementara itu, shadaqah dan infaq merupakan ibadah yang sunah dan apabila dilakukan merupakan wujud kecintaan dan rasa syukur atas kenikmatan yang telah diberikan oleh Allah SWT kepadanya sehingga seorang tersebut rela menyisihkan hartanya untuk membantu sesama.

Islam sendiri memiliki potensi untuk menekan angka kemiskinan dengan cara pemerataan ekonomi melalui sistem zakat. Hal ini merupakan potensi yang luar biasa bagi Indonesia, karena menurut Outlook Zakat 2017 yang dikeluarkan oleh PUZKAS BAZNAS menyebutkan bahwa pada tahun 2015 potensi zakat di Indonesia mencapai $286 \mathrm{~T}$ dan yang dapat terhimpun hanya se

\section{besar 3,7 T.}

Badan Amil Zakat merupakan salah satu bagian dari organisasi nirlaba yaitu organisasi yang dalam menjalankan kegiatan operasionalnya tidak bertujuan mencari keuntungan. Badan Amil Zakat dibentuk sebagai entitas yang mengelola zakat dan menyalurkannya kepada pihak yang membutuhkan juga menerapkan akuntansi dalam pencatatan transaksinya sehingga pada akhirnya dapat menghasilkan suatu informasi sebagai laporan pertanggungjawaban.

PSAK No.109 tentang zakat, infaq dan shadaqah merupakan peraturan yang wajib diterapkan oleh lembaga pengelola zakat yang mendapat izin dari pemerintah. PSAK ini bertujuan mengatur pengakuan, pengukuran, penyajian, dan pengungkapan transaksi zakat, infaq dan shadaqah. Dengan adanya PSAK ini diharapkan masyarakat luas dapat membaca laporan keuangan pengelola zakat dan dapat mengawasi pengelolaannya, sehingga terbangun kepercayaan masyarakat untuk menyerahkan zakat, infaq dan shadaqahnya kepada lembaga pengelola zakat seperti BAZNAS. 
Berdasarkan uraian di atas, maka peneliti tertarik mengambil judul mengenai "Analisis Penerapan PSAK No.109 tentang Zakat, Infaq dan Shadaqah pada Badan Amil Zakat Nasional (BAZNAS) Kabupaten Nganjuk". Dengan tujuan untuk mengetahui apakah penerapan akuntansi zakat, infaq dan shadaqah pada BAZNAS kabupaten Nganjuk sudah sesuai dengan PSAK No.109

\section{TINJAUAN PUSTAKA}

\section{Pengertian Zakat}

Zakat merupakan salah satu pilar rukun dari 5 pilar yang membentuk Islam. Zakat merupakan kewajiban bagi setiap muslim yang mampu untuk membayarnya dan dibagikan kepada mereka yang berhak menerimanya. Dari segi bahasa, zakat berasal dari kata "zaka" yang berarti berkah, tumbuh, suci, bersih dan baik, sedangkan zakat secara terminologi berarti aktivitas memberikan harta tertentu yang diwajibkan Allah SWT dalam jumlah dan perhitungan tertentu untuk diserahkan kepada orang-orang yang berhak.

Menurut UU No. 38 tahun 1999 zakat adalah harta yang wajib di sisihkan oleh seorang muslim atau badan yang dimiliki oleh orang muslim sesuai dengan ketentuan agama untuk diberikan kepada yang berhak menerimanya. Menurut Arifin (2016:5) Zakat adalah hak yang berupa harta (tertentu) yang wajib ditunaikan untuk diberikan kepada kelompok tertentu dan dalam waktu tertentu pula.

Dari beberapa pengertian diatas, peneliti menyimpulkan bahwa zakat adalah ibadah wajib bagi setiap muslim untuk mengeluarkan sebagian hartanya untuk diberikan kepada orang-orang yang berhak menerimanya guna menyucikan/membersihkan jiwa dan harta berdasarkan syarat dan waktu tertentu. Zakat wajib ditunaikan oleh setiap muslim yang hartanya sudah mencapai nasabnya sesuai dengan yang telah dijelaskan dalam Al Qur'an. Zakat akan membawa manfaat bagi pemberi dan penerima zakat.

\section{Pengertian Infak dan Sedekah}

Infak berasal dari kata anfaqa yang berarti mengeluarkan, membelanjakan (harta/uang), sedangkan menurut terminologi artinya mengeluarkan harta karena taat dan patuh kepada Allah SWT dan menurut kebiasaan yaitu untuk memenuhi kebutuhan. Pengeluaran infak dapat dilakukan oleh seorang muslim sebagai rasa syukur ketika menerima rezeki dari Allah dengan jumlah sesuai kerelaan dan kehendak muslim tersebut.

Menurut Arifin (2016:178) infak adalah mengeluarkan sebagian harta untuk suatu hajat/keperluan (yang disyariatkan oleh Ajaran Islam). Infak dikeluarkan oleh setiap orang yang beriman, baik yang berpenghasilan tinggi maupun rendah, apakah di saat lapang (berkecukupan) maupun sempit (kekurangan). Infak tidak mengenal nishab (batasan jumlah harta) dan tidak harus diberikan kepada mustahik tertentu.

\section{Landasan Kewajiban Zakat}

Menurut Nurhayati dan Wasilah (2016:285-286) terdapat 2 sumber hukum mengenai kewajiban zakat, yaitu: 


\section{Al-Quran}

Beberapa ayat Al-Quran yang membahas mengenai zakat:

"Ambillah zakat dari sebagian harta mereka, dengan zakat itu kamu membersihkan dan menyucikan mereka, dan berdoalah untuk mereka. Sesungguhnya doa kamu itu menjadi ketentraman jiwa bagi mereka. Dan Allah maha mendengar lagi maha mengetahui." (QS 9:103)

"...dan apa yang kamu berikan berupa zakat yang kamu maksudkan untuk mencapai keridhaan Allah, maka itulah orang-orang yang melipatgandakan (pahalanya)." (QS 30:39)

"...dan celakalah bagi orang orang yang mempersekutukan(Nya) (yaitu) orangorang yang tidak menunaikan zakat dan mereka kafir akan adanya (kehidupan akhirat)." (QS 41:6 dan 7)

"Sesungguhnya zakat-zakat itu hanyalah untuk orang-orang fakir, orang-orang miskin, pengurus zakat, para mualaf yang dibujuk hatinya, untuk memerdekakan budak, orang-orano yang berutang, untuk jalan Allah, dan orang-orang yang sedang dalamn perjalanan, sebagai sesuatu ketetapan yang diwajibkan Allah, dan Allah Maha Mengetahui lagi Maha Bijaksana." (QS 9:60)

\section{As-Sunah}

Abu Hurairah berkata, Rasulullah bersabda: "siapa yang dikaruniai oleh Allah kekayaan tetapi tidak mengeluarkan zakatnya, maka pada hari kiamat nanti ia akan didatangi oleh seekor ular jantan gundul yang sangat berbisa dan sangat menakutkan dengan dua bintik di atas kedua matanya."(HR Bukhari)

"Golongan yang tidak mengeluarkan zakat (di dunia) akan ditimpa kelaparan dan kemarau panjang." (HR Tabrani)

"Bila shadaqah (zakat) bercampur dengan kekayaan lain, maka kekayaan itu akan binasa" (HR Bazar dan Baihaqi)

"Zakat itu dipungut dari orang orang kaya di antara mereka, dan diserahkan kepada orang-orang miskin." (HR Bukhari)

\section{Syarat dan Wajib Zakat}

Zakat wajib dikeluarkan bagi setiap muslim. Dalam mengeluarkan zakat terdapat beberapa syarat wajib zakat. Syarat wajib zakat, antara lain sebagai berikut:

1. Islam, berarti mereka yang beragama Islam wajib mengeluarkan zakat baik anak anak atau sudah dewasa, berakal sehat atau tidak.

2. Merdeka, berarti bukan budak dan memiliki kebebasan untuk menjalankan seluruh syariat Islam.

3. Memiliki satu nisab dari salah satu jenis harta yang wajib dikenakan zakat dan cukup haul.

Kemudian syarat harta kekayaan yang wajib dizakatkan atau objek zakat adalah : halal, milik penuh, berkembang, cukup nisab, cukup haul, bebas dari utang, dan lebih dari kebutuhan pokok

\section{Jenis Zakat}

Zakat termasuk ibadah yang telah diatur secara jelas dan paten dalam Al Qur'an dan as-Sunnah. Menurut Nurhayati dan wasilah (2016:288) secara umum zakat dikelompokkan menjadi dua, yaitu: 
1. Zakat Fitrah/Zakat Jiwa adalah zakat yang diwajibkan kepada setiap muslim setelah matahari terbenam akhir bulan Ramadan. Lebih utama jika dibayarkan sebelum shalat Idul Fitri, Karena jika dibayarkan setelah shalat Ied, maka sifatnya seperti sedekah biasa bukan zakat fitrah.

2. Zakat Harta adalah zakat yang boleh dibayarkan pada waktu yang tidak tertentu, mencakup hasil perniagaan, pertanian, pertambangan, hasil laut, hasil ternak, harta temuan, emas dan perak serta hasil kerja (profesi) yang masingmasing memiliki perhitungan sendiri-sendiri.

Pada masa Rasulullah kelompok harta yang ditetapkan menjadi objek zakat terbatas pada (1) emas dan perak -di zaman Rasul uang terbuat dari emas atau perak; (2) tumbuh-tumbuhan tertentu seperti gandum, jelai, kurma dan anggur; (3) hewan ternak tertentu seperti domba atau biri-biri, sapi dan unta; (4) harta perdagangan (tijarah); (5) harta kekayaan yang ditemukan dalam perut bumi (rikaz).

\section{Penerima Zakat}

Selain telah menetapkan zakat sebagai kewajiban muslim yang telah memenuhi ketentuan tertentu seperti telah dijelaskan di atas. Allah SWT telah menentukan kepada siapa zakat itu harus diberikan. Menurut Nurhayati dan wasilah (2016:303-309) ada delapan golongan (asnaf) yang berhak menerima zakat, yaitu sebagai berikut :

1. Fakir

2. Miskin

3. Pihak yang mengurus zakat (amil)

3. Golongan Mualaf

4. Orang yang belum merdeka (Riqab)

5. Orang yang berutang (Gharimin)

6. Orang yang berjuang di jalan Allah (Fisabilillah)

7. Orang yang melakukan perjalanan (Ibnu Sabil)

\section{Badan Amil Zakat (BAZ)}

Badan amil zakat adalah organisasi pengelola zakat yang dibentuk oleh pemerintah, yang terdiri dari unsur masyarakat dan pemerintah dengan tugas mengumpulkan, mendistribusikan, dan mendayagunakan zakat sesuai dengan ketentuan agama. Terdapat tiga bentuk Badan Amil Zakat Nasional (BAZNAS) berdasarkan cakupan wilayah kerjanya, yaitu BAZNAS, BAZNAS provinsi dan BAZNAS kabupaten. Dalam menjalankan fungsinya ketiga lembaga ini memiliki hubungan kerja yang bersifat koordinatif, konsultatif dan informatif'.

Dalam melaksanakan seluruh kegiatannya badan amil zakat memiliki kewajiban yang harus dilaksanakan, yaitu :

1) Segera melakukan kegiatan sesuai dengan program kerja yang telah dibuat.

2) Menyusun laporan tahunan yang didalamnya termasuk laporan keuangan.

3) Mempublikasikan laporan keuangan tahunan yang telah di audit oleh akuntan publik atau lembaga pengawas pemerintah yang berwenang melalui media massa sesuai dengan tingkatannya, selambat-lambatnya 6 bulan setelah tahun buku terakhir. 
4) Menyerahkan laporan tersebut kepada pemerintah dan Dewan Perwakilan Rakyat sesuai dengan tingkatannya.

5) Merencanakan kegiatan tahunan.

6) Mengutamakan pendistribusian dan pendayagunaan dari dana zakat yang diperoleh di daerah masing-masing sesuai dengan tingkatannya, kecuali BAZ nasional dapat mendistribusikan dan pendayagunaan dan zakat ke seluruh wilayah indonesia.

\section{Pernyataan Standar Akuntansi Keuangan (PSAK No.109)}

Perlakuan akuntansi dalam pembahasan ini mengacu pada PSAK No. 109, ruang lingkupnya hanya untuk amil yang menerima dan menyalurkan zakat dan infak/sedekah. PSAK ini wajib diterapkan oleh amil yang mendapat izin dari regulator (pemerintah).

\section{Pengakuan dan Pengukuran}

1) Penerimaan Zakat

Penerimaan zakat diakui pada saat kas atau aset nonkas diterima. Zakat yang diterima dari muzaki diakui sebagai penambah dana zakat sebesar: (a) jumlah yang diterima, jika dalam bentuk kas; (b) nilai wajar, jika dalam bentuk nonkas.

Penentuan nilai wajar aset nonkas yang diterima menggunakan harga pasar. Jika harga pasar tidak tersedia, maka dapat menggunakan metode penentuan nilai wajar lainnya sesuai dengan SAK yang relevan.

Jika muzaki menentukan mustahik yang menerima penyaluran zakat melalui amil, maka tidak ada bagian amil atas zakat yang diterima. Amil dapat memperoleh ujrah atas kegiatan penyaluran tersebut. Ujrah ini berasal dari muzaki, di luar dana zakat. Ujrah tersebut diakui sebagai penambah dana amil.

Jika terjadi penurunan nilai aset zakat nonkas, maka jumlah kerugian yang ditanggung diperlakukan sebagai pengurang dana zakat atau pengurang dana amil bergantung pada penyebab kerugian tersebut.

Penurunan nilai aset zakat diakui sebagai: (a) pengurang dana zakat, jika tidak disebabkan oleh kelalaian amil, (b) kerugian dan pengurang dana amil, jika disebabkan oleh kelalaian amil.

2) Penyaluran Zakat

Zakat yang disalurkan kepada mustahik, termasuk amil, diakui sebagai pengurang dana zakat sebesar: (a) jumlah yang diserahkan, jika dalam bentuk kas, (b) jumlah tercatat, jika dalam bentuk aset nonkas.

Efektivitas dan efisiensi pengelolaan zakat bergantung pada profesionalisme amil. Dalam konteks ini, amil berhak mengambil bagian dari zakat untuk menutup biaya operasional dalam rangka melaksanakan fungsinya sesuai dengan kaidah atau prinsip syariah dan tata kelola organisasi yang baik.

Beban penghimpunan dan penyaluran zakat harus diambil dari porsi amil. Amil dimungkinkan untuk meminjam dana zakat dalam rangka menghimpun zakat. Pinjaman ini sifatnya jangka pendek dan tidak boleh melebihi satu periode (haul).

3) Penerimaan Infak/Sedekah

Infak/sedekah yang diterima diakui sebagai penambah dana infak/sedekah terikat atau tidak terikat sesuai dengan tujuan pemberi infak/sedekah sebesar: (1) 
jumlah yang diterima, jika dalam bentuk kas; (2) nilai wajar, jika dalam bentuk nonkas.

Penurunan nilai aset infak/sedekah tidak lancar diakui sebagai: (a) pengurang dana infak/sedekah, jika tidak disebabkan oleh kelalaian amil, (b) kerugian dan pengurang dana amil, jika disebabkan oleh kelalaian amil.

4) Penyaluran Infak/Sedekah

Penyaluran dana infak/sedekah diakui sebagai pengurang dana infak/sedekah sebesar: (a) jumlah yang diserahkan, jika dalam bentuk kas, (b) nilai tercatat aset yang diserahkan, jika dalam bentuk aset nonkas.

Penentuan jumlah atau persentase bagian untuk para penerima infak/sedekah ditentukan oleh amil sesuai dengan prinsip syariah, kewajaran, dan etika yang dituangkan dalam bentuk kebijakan amil.

\section{Penyajian}

Amil menyajikan dana zakat, dana infak/sedekah, dan dana amil secara terpisah dalam laporan posisi keuangan. Hal ini bertujuan agar memudahkan perhitungan dari seluruh dana yang ada karena telah dipisahkan. Selain itu juga memudahkan dalam pendistribusian dana, antara dana zakat dengan dana infak. Secara lengkap amil harus menyajikan laporan yang terdiri dari : laporan posisi keuangan (neraca), laporan perubahan dana, laporan perubahan aset kelola, laporan arus kas, dan catatan atas laporan keuangan.

\section{Pengungkapan Zakat}

Amil mengungkapkan hal-hal berikut terkait dengan transaksi zakat, tetapi tidak terbatas pada:

1) kebijakan penyaluran zakat, seperti penentuan skala prioritas penyaluran zakat dan mustahik nonamil;

2) kebijakan penyaluran zakat untuk amil dan mustahik nonamil, seperti persentase pembagian, alasan, dan konsistensi kebijakan;

3) metode penentuan nilai wajar yang digunakan untuk penerimaan zakat berupa aset nonkas;

4) rincian jumlah penyaluran dana zakat untuk masing-masing mustahik;

5) penggunaan dana zakat dalam bentuk aset kelolaan yang masih dikendalikan oleh amil atau pihak lain yang dikendalikan amil, jika ada, diungkapkan jumlah dan persentase terhadap seluruh penyaluran dana zakat serta alasannya; dan

6) hubungan pihak-pihak berelasi antara amil dan mustahik yang meliputi: (i) sifat hubungan; (ii) jumlah dan jenis aset yang disalurkan; dan (iii) presentase dari setiap aset yang disalurkan tersebut dari total penyaluran zakat selama periode.

\section{Pengungkapan Infak/Sedekah}

Amil mengungkapkan hal-hal berikut terkait dengan transaksi infak/sedekah, tetapi tidak terbatas pada:

1) kebijakan penyaluran infak/sedekah, seperti penentuan skala prioritas penyaluran infak/sedekah dan penerima infak/sedekah; 
2) kebijakan penyaluran infak/sedekah untuk amil dan nonamil, seperti persentase pembagian, alasan, dan konsistensi kebijakan;

3) metode penentuan nilai wajar yang digunakan untuk penerimaan infak/sedekah berupa aset nonkas;

4) keberadaan dana infak/sedekah yang tidak langsung disalurkan tetapi dikelola terlebih dahulu, jika ada, diungkapkan jumlah dan persentase dari seluruh penerimaan infak/sedekah selama periode pelaporan serta alasannya;

5) hasil yang diperoleh dari pengelolaan yang dimaksud di huruf (d) diungkapkan secara terpisah;

6) penggunaan dana infak/sedekah menjadi aset kelolaan, jika ada, diungkapkan jumlah dan persentase terhadap seluruh penggunaan dana infak/sedekah serta alasannya;

7) rincian dana infak/sedekah berdasarkan peruntukannya, terikat dan tidak terikat;

8) hubungan pihak-pihak berelasi antara amil dan penerima infak/sedekah yang meliputi: (i) sifat hubungan; (ii) jumlah dan jenis aset yang disalurkan; dan (iii) presentase dari setiap aset yang disalurkan tersebut dari total penyaluran infak/sedekah selama periode.

Selain membuat pengungkapan zakat, infaq dan shadaqah, amil mengungkapkan hal-hal berikut: (i) keberadaan dana nonhalal, jika ada, diungkapkan mengenai kebijakan atas penerimaan dan penyaluran dana, alasan, dan jumlahnya; dan (ii) kinerja amil atas penerimaan dan penyaluran dana zakat dan dana infak/sedekah.

\section{METODE}

\section{Jenis Penelitian}

Jenis penelitian yang digunakan dalam penelitian ini adalah penelitian kualitatif deskriptif dengan melakukan pendekatan studi kasus.

\section{Lokasi Penelitian}

Lokasi penelitian ini di Badan Amil Zakat Nasional (BAZNAS) Kabupaten Nganjuk yang berlokasi di jalan K.H. Wachid Hasyim No.14, Kauman, Kec.Nganjuk, Kabupaten Nganjuk.

\section{Sumber Data}

Sumber data yang digunakan dalam penelitian ini ada dua, yaitu: data primer dan data sekunder.

\section{Teknik Pengumpulan Data}

Teknik pengumpulan data yang digunakan dalam penelitian ini adalah: observasi, wawancara, dan dokumen.

\section{Teknik Analisis Data}

Teknik analisis data adalah sebagai berikut:

1) Data Reduction (Reduksi Data)

2) Data Display (Penyajian Data) 


\section{3) Conclusion Drawing/Verification (Penarikan Kesimpulan dan Verifikasi)}

\section{PEMBAHASAN}

Berdasarkan hasil wawancara dengan Bapak Ahmad Dain Arif selaku staf bidang penyaluran dan pendistribusian zakat dan Ibu Lilik Nurhayati selaku staf bidang pengumpulan, menjelaskan bahwa sumber dana zakat, infaq dan shadaqah pada BAZNAS Kabupaten Nganjuk adalah berasal dari instansi-instansi pemerintah daerah, perusahaan, dan juga masyarakat umum. Dana zakat yang diterima kebanyakan merupakan zakat harta, zakat profesi dan zakat penghasilan perusahaan. Tidak terdapat zakat fitrah yang diterima BAZNAS Kabupaten Nganjuk, hal ini dikarena pihak BAZNAS memilih menolak dan merekomendasikan untuk diserahkan ke Pengurus Masjid Agung Nganjuk yang lokasinya bersebelahan dengan BAZNAS Kabupaten Nganjuk.

Dalam mengelola dana zakat, infaq dan shadaqah, BAZNAS Kabupaten Nganjuk melakukan pencatatan pembukuan secara manual dan juga menggunakan sistem komputerisasi. Pencatatan manual dilakukan dengan menggunakan buku yang secara terpisah untuk mencatat pemasukan dan pengeluaran, sedangkan sistem komputerisasi (microsoft excel) digunakan untuk merekap dana keluar masuk yang kemudian akan digunakan untuk membuat laporan keuangan. Selain itu, terdapat sistem khusus dari BAZNAS pusat bernama SIMBA yang diakses BAZNAS Kabupaten Nganjuk untuk melaporkan aktivitasnya kepada BAZNAS pusat. Sistem pembukuan yang dilakukan BAZNAS Kabupaten Nganjuk adalah menggunakan cash basis, dimana setiap transaksi yang terjadi dicatat berdasarkan jumlah nominal kas yang diterima.

Dana zakat, infaq dan shadaqah yang disalurkan sesuai dengan delapan asnaf (golongan). Dalam penyaluran dana zakat, infaq dan shadaqah BAZNAS Kabupaten Nganjuk tidak memiliki program besar khusus yang setiap tahun ada seperti bedah rumah dan khitanan masal yang pernah dilaksanakan pada tahun 2018. BAZNAS Kabupaten Nganjuk lebih banyak melakukan penyaluran rutin seperti santunan kepada fakir miskin, yatim piatu dan janda jompo, bakti sosial, beasiswa pendidikan anak kurang mampu, bantuan untuk kaum duafa dan orang sebatangkara, bantuan perjalanan musafir, dan bantuan biaya pengobatan.

\section{Perbandingan Pencataan Menurut PSAK No.109 Dengan BAZNAS Kabupaten Nganjuk}

1. Pengakuan Awal Penerimaan Zakat

Berdasarkan hasil wawancara, dijelaskan bahwa pada saat penerimaan dana baik zakat, infaq atau shadaqah langsung dicatat dalam buku penerimaan dana oleh bendahara bagian pengumpulan dengan mencatat nama penyetor dan jumlah nominalnya. Sedangkan menurut PSAK No.109, penerimaan dana zakat diakui pada saat kas atau aset nonkas diterima dan diakui sebagai penambah dana zakat. Zakat yang diterima dari muzzaki diakui sebagi penambah dana zakat.

Dijelaskan juga bahwa terdapat muzaki yang menentukan mustahik sendiri. Salah satunya meminta untuk zakatnya disalurkan kepada anak yatim. Namun dana untuk amil tidak berupa ujrah yang diluar dana zakat, melainkan menjadi 
satu dengan dana zakat yang disetorkan. Sedangkan menurut PSAK No.109, jika muzakki menentukan mustahik yang menerima penyaluran zakat melalui amil, maka tidak ada bagian amil atas zakat yang diterima. Amil dapat memperoleh ujrah atas kegiatan penyaluran tersebut. Ujrah ini berasal dari muzaki, di luar dana zakat. Ujrah tersebut diakui sebagai penambah dana amil.

\section{Pengukuran Saat Terjadi Penurunan Nilai}

Berdasarkan hasil wawancara, dijelaskan bahwa BAZNAS Kabupaten Nganjuk tidak pernah menerima dana nonkas, sehingga tidak ada perhitungan dan pencatatatan penurunan nilai. Dalam PSAK No.109 dijelaskan jika terjadi penurunan nilai aset zakat nonkas, maka jumlah kerugian yang ditanggung diperlakukan sebagai pengurang dana zakat atau pengurang dana amil bergantung pada penyebab kerugiannya. Penuruan nilai aset zakat diakui sebagai berikut: (a) pengurang dana zakat, jika terjadi tidak disebabkan oleh kelalain amil, (b) erugian dan pengurang dana amil, jika disebabkan oleh kelalaian amil.

\section{Penyaluran Zakat}

Berdasarkan hasil wawancara, dijelaskan bahwa saat penyaluran, bagian penyaluran mengisi kwitansi terlebih dahulu sejumlah nominal yang dibutuhkan untuk membuat surat permintaan pembayaran yang kemudian diserahkan ke bedahara untuk dimintakan dana. Untuk dana bagian amil, dijelaskan bahwa setiap awal bulan BAZNAS Kabupaten Nganjuk menghitung dan mengambil dana bagian amil sebesar 10\% dari total dana zakat yang terkumpul. Sedangkan, menurut PSAK No.109 zakat yang disalurkan kepada mustahik, termasuk amil, diakui sebagai pengurang dana zakat sebesar: (a) jumlah yang diserahkan, jika dalam bentuk kas, (b) jumlah tercatat, jika dalam bentuk aset nonkas.

Beban penghimpunan dan penyaluran zakat harus diambil dari porsi amil. Amil dimungkinkan untuk meminjam dana zakat dalam rangka menghimpun zakat. Pinjaman ini sifatnya jangka pendek dan tidak boleh melebihi satu periode (haul).

\section{Penerimaan Infaq/Shadaqah}

Berdasarkan hasil wawancara, dijelaskan bahwa pada saat penerimaan baik zakat, infaq atau shadaqah langsung dicatat dalam buku penerimaan dana oleh bendahara bagian pengumpulan dengan mencatat nama penyetor dan jumlah nominalnya. Infaq/shadaqah yang diterima BAZNAS Kabupaten Nganjuk tidak ada yang berupa nonkas dan tidak ada yang terikat tujuan terterntu sesuai dengan amanah pemberi infaq/shadaqah. Sedangkan menurut PSAK No.109, infaq/shadaqah yang diterima diakui sebagai penambah dana infaq/shadaqah terikat atau tidak terikat sesuai dengan tujuan pemberi infaq/shadaqah sebesar: (1) jumlah yang diterima, jika dalam bentuk kas; (2) nilai wajar, jika dalam bentuk nonkas. Aset tidak lancar yang diterima dan diamanahkan untuk dikelola oleh amil diukur sebesar nilai wajar saat penerimaan dan diakui sebagai aset tidak lancar infak/sedekah.

\section{Pengukuran Saat Terjadi Penurunan Nilai}

Berdasarkan hasil wawancara, dijelaskan bahwa BAZNAS Kabuaten Nganjuk tidak pernah menerima dana nonkas, sehingga tidak ada perhitungan dan 
pencatatatan penurunan nilai. Menurut PSAK No.109, penurunan nilai aset infak/sedekah tidak lancar diakui sebagai: (a) pengurang dana infak/sedekah, jika tidak disebabkan oleh kelalaian amil, (b) kerugian dan pengurang dana amil, jika disebabkan oleh kelalaian amil.

\section{Penyaluran Infak/Sedekah}

Berdasarkan hasil wawancara, dijelaskan bahwa saat penyaluran, bagian penyaluran mengisi kwitansi terlebih dahulu sejumlah nominal yang dibutuhkan untuk membuat surat permintaan pembayaran yang kemudian diserahkan ke bedahara untuk dimintakan dana. Sedangkan menurut PSAK No.109 Penyaluran dana infaq/shadaqah diakui sebagai pengurang dana infaq/shadaqah sebesar: (a) jumlah yang diserahkan, jika dalam bentuk kas, (b) nilai tercatat aset yang diserahkan, jika dalam bentuk aset nonkas.

Sesuai dengan ketentuan BAZNAS Kabupaten Nganjuk, dana bagian amil diambil sebesar $20 \%$ dari total dana infaq/shadaqah yang terkumpul. Dalam penyaluran dana infaq/shadaqah, BAZNAS Kabupaten Nganjuk lebih ke bantuan seperti pembagunan masjid dan bedah rumah. Sedangkan menurut PSAK No.109 bagian dana infak/sedekah yang disalurkan untuk amil diakui sebagai penambah dana amil. Penentuan jumlah atau persentase bagian untuk para penerima infak/sedekah ditentukan oleh amil sesuai dengan prinsip syariah, kewajaran, dan etika yang dituangkan dalam bentuk kebijakan amil.

\section{Penyajian Zakat dan Infaq/Shadaqah}

Berdasarkan data laporan keuangan yang diberikan, BAZNAS Kabupaten Nganjuk menyajikan dana zakat dan infaq/shadaqah secara terpisah. Namun untuk dana bagian amil tidak ditampilkan. Laporan yang disajikan BAZNAS Kabupaten Nganjuk tidak dalam bentuk laporan posisi keuangan tetapi hanya berupa daftar penerimaan dan pengeluaran dana zakat, infaq dan shadaqah. Menurut PSAK No.109, amil harus menyajikan dana zakat, dana infaq/shadaqah, dan dana amil secara terpisah dalam laporan posisi keuangan. Selain laporan posisi keuangan, secara lebih lengkap amil juga harus menyajikan laporan perubahan dana, laporan perubahan aset kelola, laporan arus kas, dan catatan atas laporan keuangan.

\section{Pengungkapan}

Berdasarkan dari data laporan, BAZNAS Kabupaten Nganjuk tidak memuat informasi mengenai penentuan skala prioritas penyaluran dan penerimaan, persentase pembagian, alasan, konsistensi kebijakan, metode penentuan nilai wajar, keberadaan asset nonkas kelolaan yang dikelola, serta hubungan pihakpihak berelasi antara amil dan mustahik. Namun BAZNAS Kabupaten Nganjuk memuat informasi rincian jumlah penyaluran dan telah mengungkapkan dana nonhalal. Sedangkan menurut PSAK No.109, amil harus mengungkapkan hal-hal terkait dengan transaksi zakat dan infaq/shadaqah, seperti kebijakan penentuan skala prioritas penyaluran dan penerimaan, persentase pembagian, alasan, konsistensi kebijakan, metode penentuan nilai wajar, rincian jumlah penyaluran , keberadaan aset nonkas kelolaan yang dikelola, serta hubungan pihak-pihak berelasi antara amil dan mustahik. Selain membuat pengungkapan zakat, infaq 
dan shadaqah, amil mengungkapkan hal-hal terkait keberadaan dana nonhalal dan kinerja amil atas penerimaan dan penyaluran dana zakat dan infak/sedekah.

\section{Kesesuaian Laporan Keuangan BAZNAS Kabupaten Nganjuk Dengan PSAK No. 109.}

Dalam mengelola dana zakat, infaq dan shadaqah lembaga pengelola zakat harus menyajikan laporan keuangan. Sesuai dengan Pernyataan Standar Akuntansi Keuangan (PSAK) No. 109 tentang akuntansi zakat, infaq/shadaqah telah dijelaskan bahwa terdapat 5 komponen laporan keuangan yang harus disajikan oleh amil. Laporan tersebut terdiri dari : (1) Laporan Posisi Keuangan, (2) Laporan Perubahan Dana, (3) Laporan Perubahan Aset Kelolaan, (4) Laporan Arus Kas, dan (5) Catatan Atas Laporan Keuangan.

Berdasarkan hasil analisis di atas, BAZNAS Kabupaten Nganjuk belum menerapkan PSAK No. 109 Tentang Akuntansi Zakat, Infaq/Shadaqah. Hal ini dibuktikan dengan tidak sesuainya pengelolaan transaksi dan beberapa hal yang diatur dalam PSAK No. 109 terkait pengakuan, pengukuran setelah pengakuan, penyajian dan pengungkapannya. BAZNAS Kabupaten Nganjuk dalam pencatatan hanya menggunakaan sistem single entry, sehingga tidak terdapat keterangan debet dan kredit dan hal tersebut tidak sesuai dengan PSAK No. 109. Selain itu, dilihat dari penyajian laporan BAZNAS Kabupaten Nganjuk tidak menyajikan 5 komponen laporan keuangan yang harus disajikan oleh amil. Dalam penyajian laporan keuangan, BAZNAS Kabupaten Nganjuk juga tidak melaporkan dana amil dalam laporan posisi keuangan dan belum mengungkapkan kebijakan-kebijakan terkait pengelolaan dana zakat, infaq dan shadaqah.

BAZNAS Kabupaten Nganjuk belum menerapkan PSAK No. 109 tentang Akuntansi Zakat, Infaq/Shadaqah dikarena kurangnya kemampuan pegawainya. Hal ini dilatar belakangi oleh pendidikan terakhir pengawai dan staff BAZNAS Kabupaten Nganjuk yang kebanyakan lulusan sarjana keagamaan. Apalagi untuk staf bagian keuangan yang seharusnya memiliki kemampuan di bidang keuangan, sehingga kegiatan pencatatan dan pelaporan lebih tertata dengan baik dan sesuai dengan peraturan.

\section{KESIMPULAN DAN SARAN}

\section{Kesimpulan}

BAZNAS Kabupaten Nganjuk dalam mengelola zakat, infaq dan shadaqah hanya melakukan pencatatan manual dan sistem komputerisasi. Pencatatan manual berupa catatan penerimaan dan pengeluaran, sedangkan sistem komputerisasi menggunakan aplikasi microsoft excel dan aplikasi khusus dari BAZNAS pusat berupa aplikasi SIMBA. Dari pencatatan tersebut kemudian disajikan rincian daftar penerimaan zakat dan laporan ringkas terkait penerimaan dan pengeluaran dana zakat, infaq dan shadaqah.

BAZNAS Kabupaten Nganjuk belum menerapkan PSAK No. 109 tentang Akuntansi Zakat, Infaq dan Shadaqah. Hal tersebut dibuktikan dengan tidak sesuainya pengelolaan transaksi dan beberapa hal yang diatur dalam PSAK No. 109 terkait pengakuan, pengukuran setelah pengakuan, penyajian dan pengungkapannya. Dan dibuktikan juga dengan tidak disajikannya 5 komponen 
laporan keuangan, yaitu : laporan posisi keuangan, laporan perubahan dana, laporan perubahan aset kelolaan, laporan arus kas, dan catatan atas laporan keuangan. Selain itu, belum disajikan dana bagian amil dalam laporan posisi keuangan dan belum diungkapkan kebijakan terkait penyaluran dana zakat, infaq dan shadaqah untuk amil dan mustahik nonamil.

\section{Saran}

Diharapkan BAZNAS Kabupaten Nganjuk dalam mengelola dana zakat, infaq dan shadaqah harus sesuai dengan pedoman dan peraturan yang berlaku, yaitu PSAK No.109. Dalam pencatatan penerimaan dan pengeluaran seharusnya menggunakan sistem double entry, yang mana pencatatan lebih mudah pengklasifikasian akun dan jumlah nominalnya. Hendaknya BAZNAS Kabupaten Nganjuk merekrut pegawai bagian keuangan yang secara khusus ahli di bidang akuntansi, sehingga dapat menyajikan 5 komponen laporan keuangan sebagai laporan pertangungjawaban sesuai dengan yang telah diatur dalam PSAK No.109.

\section{DAFTAR PUSTAKA}

Arifin. (2016). Zakat, Infaq, Sedekah. Jakarta : PT. Elex Media Komputindo.

Badan Amil Zakat Nasional. (2017). Outlook Zakat Indonesia 2017. Jakarta: Pusat Kajian Strategis BAZNAS.

Ikatan Akuntansi Indonesia. (2017). Standar Akuntansi Keuangan Syariah. Jakarta.

Keputusan Menteri Agama (KMA) Nomor 118 Tahun 2014 tentang Pembentukan Badan Amil Zakat Provinsi.

Nurhayati, Sri dan Wasilah. (2016). Akuntansi Syariah di Indonesia (Edisi 4). Jakarta : Salemba Empat.

Republik Indonesia, Undang-Undang Nomor 38 Tahun

1999

Tentang Pengelolaan Zakat.

Republik Indonesia, Undang-Undang Nomor 23 Tahun $2011 \quad$ Tentang Pengelolaan Zakat.

Sugiyono. (2017). Metode Penelitian Kuantitatif, Kualitatif dan Kombilasi (Mixed Methods). Bandung : Alfabeta. 